\title{
Numerical Study on the Mechanism of Water Inrush by Floor Damage and Fault Activation during Longwall Mining
}

\author{
Peisen Zhang \\ State Key Laboratory of Mining \\ Disaster Prevention and Control \\ College of Mining and Safety Shandong \\ University of Science and Technology \\ Qingdao, China \\ peisen_sky@163.com \\ Hao Wang \\ Anti-shock office \\ Shandong New Dragon Energy Co. Ltd. \\ Heze, China \\ 810504176@qq.com
}

\author{
Wei Yan \\ State Key Laboratory of Mining \\ Disaster Prevention and Control \\ College of Mining and Safety Shandong \\ University of Science and Technology \\ Qingdao, China \\ yanwei_sdust@163.com
}

\author{
Wenquan Zhang \\ State Key Laboratory of Mining \\ Disaster Prevention and Control \\ College of Mining and Safety Shandong \\ University of Science and Technology \\ Qingdao, China \\ wenquanzhang@163.com
}

\begin{abstract}
This study evaluated the damage and fracture patterns in mine floors and the fault activation caused by longwall mining, as well as the associated effects on mine water inrush. Numerical simulations were used for this evaluation. The results indicated that higher water pressures in confined aquifers and the existence of faults can increase the probability of water inrush in deep coal seams. A wider coal pillar at the fault can help prevent water inrush events. Numerical simulations were used to demonstrate the complete process of fracture development in the floor, fault activation, and formation of water inrush channels during longwall mining. This study improved the understanding of the mechanisms of water inrush through the fault zone. The results of this study are important to the design of water-resistant coal pillars in active coal seams above confined aquifers with faults
\end{abstract}

Keywords-hydro-mechanical coupling, floor damage, fault activation, mechanism of water inrush

\section{INTRODUCTION}

Shallow mineral deposits in China are facing depletion. The average depth of coal mining is increasing at a rate of 15 to $30 \mathrm{~m}$ per year, and there are currently 39 mines with depths of over a thousand metres. Many more mines are predicted to reach excavation depths of 1000 to $1500 \mathrm{~m}$ by 2030. The geological conditions of deep mining strata are becoming more complex, and the difficulty of excavation has significantly increased. Presently, water inrush due to fault activation is a primary issue in deep mining [1-2].

According to a statistical survey, 151 accidents due to water inrush occurred in Chinese mines between 2009 and 2012, causing 704 casualties. Water inrush induced by the excavation of coal seams primarily occurs at tectonic perturbation sites, especially in the vicinity of faults. A statistical analysis indicated that more than $80 \%$ of water inrush events in coal mines are related to the geological structure [3], which provides the main channel of water inrush. Water inrush is caused by a number of factors [4-5], including structural properties, the confined water pressure, and mining activity, among others. The activation of a fault generates new fractures in the vicinity of the fault zone. The existing fractures propagate and coalesce to form a water inrush channel, causing water inrush at the longwall face [6].

Observing the timing, location, and cause of water inrush due to fault activation is vital. Since the 1940s, numerous measures have been implemented in coal mines to prevent water hazards. Additionally, various theories and methods have been developed, including the theoretical profiling of the safe water pressure of the floor [7], the critical strength theory of rock, calculation of the water inrush coefficient [810], design methods for the relative thickness of the confining bed, the stress relationship between water and rock, analyses of high-permeability channels, and the development of the stratum model theory [11], among others. Although the effects of mining and geological factors on the water resistance capacity of the floor are considered from different perspectives in the above theories, previous studies have been largely based on theoretical analysis and assumptions, and the relationship between the effect of mining and water inrush has rarely been considered. A number of fault activation studies have been conducted based on mine pressure, hydrogeologic and geomechanical engineering theories, such as the floor-three-zone theory [12-13], the theory of in-situ rifting and zero failure [14], the key stratum (KS) theory [15], etc. The aforementioned theories consider the key factors that impact geological structures, as well as mining effects, qualitatively explaining the connections between those factors and water inrush via the floor. In addition, some studies considered these key factors using different methods. Hu [16] analysed the activation patterns of invisible faults in the floor. Additionally, some studies [1719] focused on fault activation mechanisms and faultinduced fracture zones affected by mining using physical models; however, the effects of water bodies with different pressures on water inrush due to fault activation have not been considered. The influences of fault activation on a loadbearing floor were analysed in the context of mining using a seepage-stress coupled model in porous media [20-22]. In addition, the characteristics of slipping and stress variations in a fault during the mining process on the working face were discussed using a fluid-solid coupled model [23-25]. The 
mechanism of water inrush at the fault floor has also been explained by numerical simulations [26-30]. However, these previous studies mainly focused on the effect of a single factor on water inrush. When mining in a confined aquifer, water inrush via a fault is the result of comprehensive actions associated with the lithological characteristics of the surrounding rock masses, the geological structure (faults and cracks), and the geological environment (stress, seepage, temperature, hydrology, etc.). These actions are further influenced by mining activity. Therefore, it is of theoretical significance and practical value to quantitatively characterize the relationship between the degree of fault activation, fault occurrence, water pressure and the effect of mining. This relationship can be investigated by combining physical model studies and numerical simulations, with the goal of determining the critical width of barrier coal pillar at a fault.

In this study, Fault F16 in the Wugou coal mine was selected for analysis. A combined approach was used to evaluate the mechanism of excavation-induced water inrush at the fault, using numerical simulations. In numerical simulation study, a coupled fluid-solid function in a threedimensional, explicit finite-difference program, FLAC3D, was used to study the displacement field, stress field and damage pattern of the hanging wall and footwall of the fault during the mining process. This numerical model was also used to analyse the coal pillar at the fault. A comprehensive analysis was performed to provide insight into the mechanism of fault activation and rock fracturing under the combined actions of the mining stress field and seepage field. This study provides a foundation for the determination of a safe width of water-resistant coal pillar close to a fault.

\section{SUMMARY OF GEOLOGICAL CONDITIONS}

The Wugou coal mine in the Wanbei Coal-Electricity Group is located in the Linhuan minefields, Huaibei coal mine district, Anhui Province, China. The geographical location and regional geological conditions are illustrated in Fig. 1 [31-33]. The mine is oriented in a triangular layout, with a narrow southern end and a wide northern end. The general structural configuration of the minefield is a syncline. The southern portion gradually changes from a north-south syncline in the north to a north-west syncline in the south. The axial region of the syncline forms a reverse " $\mathrm{S}$ " shape, and a sublevel anticline has developed within the syncline. The slope angle of the ground is generally $10^{\circ}$ to $20^{\circ}$, and the axial direction of the fold is twisted in a NE-NNE direction at the southern end of the mine. Nineteen jointed faults have developed in the minefield, all of which are normal faults. Among these faults, seven have throws greater than $100 \mathrm{~m}$, one has a throw between 100 and $50 \mathrm{~m}$, three have throws between 50 and $30 \mathrm{~m}$, and eight have throws less than $30 \mathrm{~m}$. The primary direction of the distribution of faults is approximately northeast. Only the Wugou fault, which is located at the central northern boundary, has an east-west orientation.

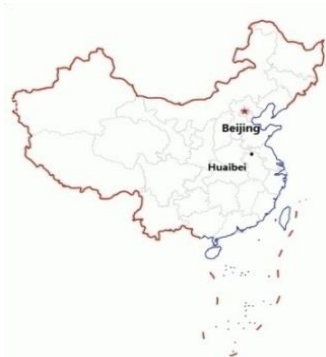

(a) Diagram of the geographical location.

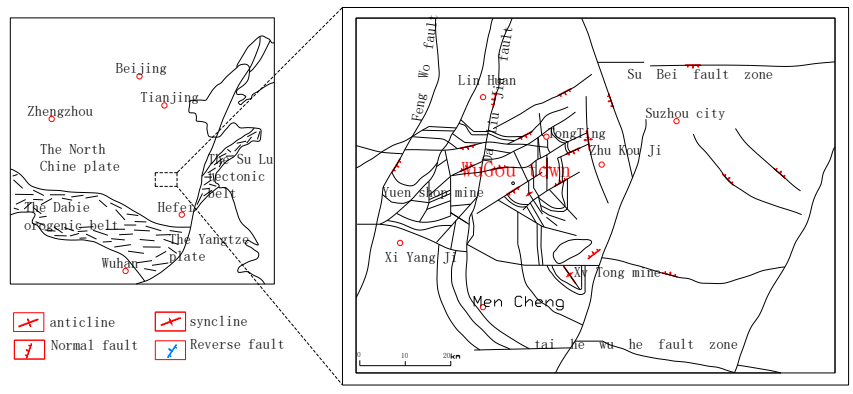

(b) Regional geological conditions.

Fig. 1 (a) Diagram of the geographical location. (b) Regional geological conditions.

Fault F16 is a normal fault that is located at the northwestern boundary of the No. 3 mining region of the Wugou coal mine, adjacent and essentially parallel to the air return roadway of Longwall Panel 1031 (Fig. 2). A 3D seismic investigation showed that Fault F16 dislocates the No. 10 coal seam from the Ordovician Limestone, with a NEE strike direction, a SSW dipping direction, a dip angle of $70^{\circ}$, a throw of 10 to $150 \mathrm{~m}$, and an extended length of 2.24 $\mathrm{km}$. The width of Panel 1031 is $110 \mathrm{~m}$. The No. 10 coal bed is the active mining seam, with an elevation of $-543 \mathrm{~m}$ to $303 \mathrm{~m}$. The dip angle is $3^{\circ}$ to $16^{\circ}$, with an average value of $8^{\circ}$. The thickness of the coal seam is $1.6 \mathrm{~m}$ to $5.4 \mathrm{~m}$, with an average of $3.98 \mathrm{~m}$. The distance between the floor of the No. 10 coal seam and the limestone stratum is $32 \mathrm{~m}$ to $67.38 \mathrm{~m}$, with an average of $47.2 \mathrm{~m}$.

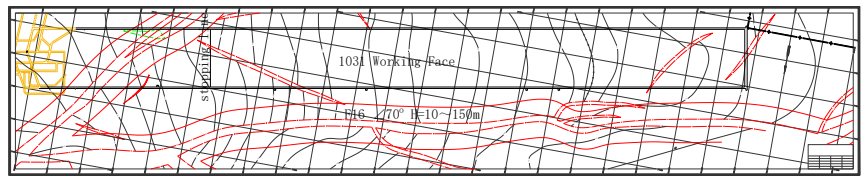

Fig. 2 Plan view of the spatial relationship between Fault F16 and Working Face 1031.

\section{NUMERICAL SIMULATION}

\section{A. Calculation Model}

Numerical models were generated using FLAC3D, a three-dimensional explicit finite-difference programme, to investigate the mechanism of water inrush due to floor damage and fault activation induced by longwall mining [34].

The advancing direction of the working face was parallel to Fault F16; thus, a plane strain model was selected without considering the effects of the advancement of the working face $[27,29,35]$. Based on detailed geological records of Panel 1031, the direction of inclination of the working face was set as the $\mathrm{X}$-axis, the direction of advancement of the working face was set as the Y-axis, and the vertical direction of the model was set as the Z-axis. Additionally, based on the boundary effect, the ratio of the height of the fracture zone to 
the mining height, the damage depth of the coal seam floor, and the calculation speed, the dimensions of the model were set to $730 \mathrm{~m} \times 8 \mathrm{~m} \times 176 \mathrm{~m}$. The meshing is illustrated in Fig. 3 . The model included 11,250 elements and 17,640 nodes.

The normal displacements at all the side and bottom boundaries of the model were fixed using "roller boundary conditions". The upper boundary was the stress boundary, and the load was determined by the weight of the overlying rock stratum [27]. In this study, the distribution of cracks, the seepage characteristics of the floor, and the slipping damage patterns of the fault surface were evaluated. Thus, interface elements were inserted into both sides of the fault $[34,36]$. The excavation of the coal seam was simulated at the hanging wall surface of a normal fault, and the roof was controlled by natural caving.

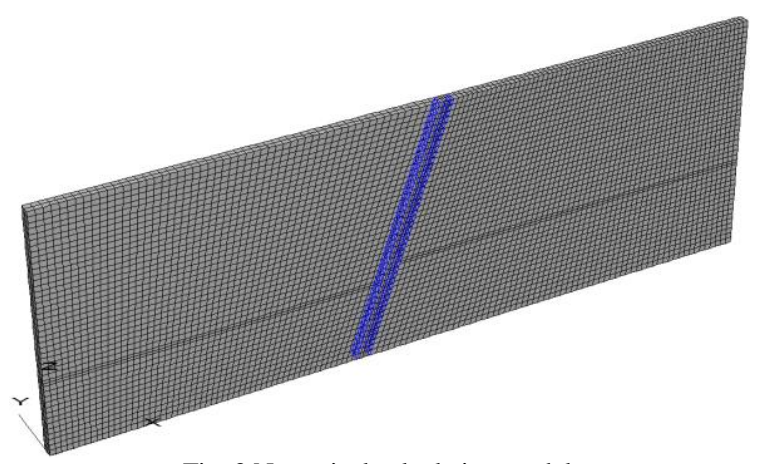

Fig. 3 Numerical calculation model

$$
f_{s}=\sigma_{1}-\sigma_{3}(1+\sin \varphi) /(1-\sin \varphi)-2 c \times \sqrt{(1+\sin \varphi) /(1-\sin \varphi)}
$$

where $\sigma_{1}$ and $\sigma_{3}$ are the maximum and minimum principle stresses, respectively, and $\varphi$ and $\mathrm{c}$ are the frictional angle and cohesion, respectively. When $f_{s}>0$, shear damage occurs. In a normal stress state, the tensile strength of the rock is low. Therefore, the tensile damage of the rock can be determined by the tensile strength criterion $\sigma_{3} \geqslant \sigma_{1}$.

\section{B. Model Selection and Parameter Determination}

Previous rock mechanic tests and engineering applications showed that the Mohr-Coulomb criterion effectively represents the damage characteristics of rocks [37]. The Mohr-Coulomb model and the FL_ISO model [34] were used in this study. The failure envelope of the MohrCoulomb model corresponds to a Mohr-Coulomb criterion (shear yield function) with a tension cutoff (tension yield function). The position of a stress point on this envelope is controlled by a non-associated flow rule of shear failure, as well as an associated rule of tension failure. The FL_ISO Model is applied in all zones in which isotropic flow can occur. Detailed information regarding the Mohr-Coulomb model and the FL_ISO model can be found in the reference manual [34].

The Mohr-Coulomb yield criterion was used to judge the damage to the rock as follows:

TABLE I. MECHANICAL PARAMETERS OF THE MAIN ROCK STRATA

\begin{tabular}{|c|c|c|c|c|c|c|c|c|}
\hline Rock layer & $\begin{array}{c}\text { Elastic bulk } \\
\text { modulus } \\
(\mathrm{K} / \mathrm{GPa})\end{array}$ & $\begin{array}{c}\text { Elastic shear } \\
\text { modulus } \\
(\mathrm{G} / \mathrm{GPa})\end{array}$ & $\begin{array}{l}\text { Cohesion } \\
\text { (c/MPa) }\end{array}$ & $\begin{array}{c}\text { Internal } \\
\text { angle of } \\
\text { friction } \\
\left(\varphi /^{\circ}\right)\end{array}$ & $\begin{array}{c}\text { Tension } \\
\text { limit } \\
\left(\sigma_{t} / \mathbf{M P a}\right)\end{array}$ & $\begin{array}{l}\text { Permeabilitycoefficient } \\
\qquad\left(\mathrm{k} / \mathrm{cm} \mathrm{s}^{-1}\right)\end{array}$ & $\begin{array}{l}\text { Porosity } \\
\text { (n) }\end{array}$ & $\begin{array}{c}\text { Density } \\
\left(\rho / \mathrm{kg} \mathrm{m}^{-3}\right)\end{array}$ \\
\hline Limestone & 41.0 & 27.0 & 4.0 & 30 & 1.75 & $0.13 \mathrm{E}-1$ & 0.52 & 2760 \\
\hline Siltstone & 17.7 & 10.6 & 5.0 & 32 & 1.72 & $3.59 \mathrm{E}-4$ & 0.25 & 2600 \\
\hline Coal seam & 1.31 & 0.71 & 1.0 & 28 & 0.55 & $4.07 \mathrm{E}-3$ & 0.35 & 1400 \\
\hline Fine sandstone & 23.5 & 19.2 & 7.5 & 35 & 2.2 & $1.23 \mathrm{E}-3$ & 0.30 & 2620 \\
\hline Fault & 0.27 & 0.21 & 1.5 & 26 & 0.1 & $4.07 \mathrm{E}-2$ & 0.44 & 2000 \\
\hline
\end{tabular}

TABLE II. PARAMETERS OF THE SuRfaCE ElEMENTS

\begin{tabular}{|c|c|c|c|c|}
\hline & $\begin{array}{c}\text { Shear stiffness } \\
\left(\mathbf{k}_{\mathbf{S}} / \mathbf{G P a}\right)\end{array}$ & $\begin{array}{c}\text { Normal stiffness } \\
(\mathbf{k n} / \mathbf{G P a})\end{array}$ & $\begin{array}{l}\text { Internal angle of friction } \\
\qquad\left(\varphi /^{\circ}\right)\end{array}$ & $\begin{array}{c}\text { Tensile limit } \\
\left(\sigma_{t} / \mathbf{M P a}\right)\end{array}$ \\
\hline Interface & 38.5 & 38.5 & 32.0 & 2.2 \\
\hline
\end{tabular}

\section{Initial Stress State}

The distribution of terrestrial stress exhibits considerable spatial differences and varies constantly with time. However, with respect to the design period of the working face, the time factor can be ignored, i.e., viewed as a stress field that is relatively stable. The vertical in-situ stress is determined by the overburden pressure as follows:

$$
\sigma_{v}=\gamma H
$$

According to geological investigations and on-site experimental studies that considered the size effect of the rock, the mechanical parameters of the main rock strata used in the simulation are shown in Table 1, and the parameters of the surface elements are shown in Table 2. where $\gamma$ and $H$ are the unit weight of rock and the depth below the ground surface, respectively.

According to the in-situ stress values measured at different locations worldwide by Brown and Hoek [38],a statistical analysis, and the fitting of 578 sets of in-situ stress data by Zhao. [39], the magnitudes of the maximum and minimum horizontal stresses were determined as follows:

$$
K_{\text {max }}=673 / H+1.3
$$




$$
\begin{aligned}
& K_{\text {min }}=41 / H+0.4 \\
& \sigma_{H \text { max }}=K_{\text {max }} \times \sigma_{v} \\
& \sigma_{H \text { min }}=K_{\text {min }} \times \sigma_{v}
\end{aligned}
$$

ring Ressetch ( (3) and (4). The unit weight of the overlying rocks was assumed to be $22.0 \mathrm{KN} / \mathrm{m} 3$, and the depth at the top boundary of the model was sequentially set to $200 \mathrm{~m}, 300 \mathrm{~m}$, $400 \mathrm{~m}, 500 \mathrm{~m}, 600 \mathrm{~m}$ and $644 \mathrm{~m}$. The calculated initial stresses applied during the calculations are shown in Table 3.

where is the ratio of horizontal stress to vertical in-situ

\begin{tabular}{|c|c|c|c|c|c|c|}
\hline Depth (m) & Kmax & Kmin & $\underset{\left(K N / \mathbf{m}^{3}\right)}{\mathbf{r}}$ & $\begin{array}{c}\sigma \mathrm{V} \\
(\mathrm{MPa})\end{array}$ & $\begin{array}{c}\text { бHmax } \\
\text { (MPa) }\end{array}$ & $\begin{array}{c}\sigma \mathrm{Hmin} \\
(\mathrm{MPa})\end{array}$ \\
\hline 200 & 4.67 & 0.61 & 22 & 4.40 & 20.53 & 2.66 \\
\hline 300 & 3.54 & 0.54 & 22 & 6.60 & 23.39 & 3.54 \\
\hline 400 & 2.98 & 0.50 & 22 & 8.80 & 26.25 & 4.42 \\
\hline 500 & 2.65 & 0.48 & 22 & 11.00 & 29.11 & 5.30 \\
\hline 600 & 2.42 & 0.47 & 22 & 13.20 & 31.97 & 6.18 \\
\hline 644 & 2.35 & 0.46 & 22 & 14.17 & 33.22 & 6.57 \\
\hline
\end{tabular}
stress. Thus, the maximum and minimum stresses expressed

TABLE III. INITIAL STATES OF TERRESTRIAL STRESS AT DIFFERENT DEPTHS

\section{Modelling Scenarios}

Previous research has shown that the activation pattern of a fault surface is related to a number of factors [5,27,34]. Activation is more likely to occur at the upper edge of a normal fault during excavation of a coal seam [40]. The stiffness of the fault surface exerts little influence on the degree of activation [36], and the higher the slope angle of the fault is, the more likely that activation occurs [27]. For these reasons, the displacement field, stress field, and damage pattern in the rock within the fault zone, at the fault surface, and at the water-resistant coal pillar in the fault were analysed during mining of the working face of the coal seam. Mining occurred at the hanging wall surface of the fault under the effects of varying factors, such as the burial depth of the coal seam, pressure of confined water, throw of the fault, and widths of the water-resistant coal pillar.

Table 4 provides a list of the simulated models. Seventeen models were incorporated into the calculations. These were categorized into four groups to examine the effects of different burial depths of the coal seam, pressures of confined water, throws of the fault, and widths of the water-resistant coal pillar. Three of these factors were fixed, and one was varied in each group to observe the effect of the variable factor. These parameters were determined by an orthogonal methodology using the geological records of

\begin{tabular}{|c|c|c|c|c|}
\hline Model & $\begin{array}{l}\text { Coal burial depth } \\
\qquad(H / m)\end{array}$ & $\begin{array}{c}\text { Fault throw } \\
\qquad(\mathrm{T} / \mathrm{m})\end{array}$ & $\begin{array}{c}\text { Water pressure } \\
\text { (P/MPa) }\end{array}$ & $\begin{array}{l}\text { Coal pillar width } \\
(\mathrm{L} / \mathrm{m})\end{array}$ \\
\hline 1 & 356 & 12 & 2 & 47 \\
\hline 2 & 456 & 12 & 2 & 47 \\
\hline 3 & 556 & 12 & 2 & 47 \\
\hline 4 & 656 & 12 & 2 & 47 \\
\hline 5 & 756 & 12 & 2 & 47 \\
\hline 6 & 800 & 12 & 2 & 47 \\
\hline 7 & 456 & 36 & 2 & 47 \\
\hline 8 & 456 & 52 & 2 & 47 \\
\hline 9 & 456 & 68 & 2 & 47 \\
\hline 10 & 456 & 108 & 2 & 47 \\
\hline 11 & 456 & 12 & 1 & 47 \\
\hline 12 & 456 & 12 & 3 & 47 \\
\hline 13 & 456 & 12 & 3.5 & 47 \\
\hline 14 & 456 & 12 & 2 & 26 \\
\hline 15 & 456 & 12 & 2 & 35 \\
\hline 16 & 456 & 12 & 2 & 43 \\
\hline 17 & 456 & 12 & 2 & 52 \\
\hline
\end{tabular}
Panel 1031.

TABLE IV. MODELLING SCENARIOS

\section{E. Monitoring Plan}

Twelve vertical displacement measurement points and eleven vertical stress measurement points were established on the water-resistant coal pillar to record the effects of different impact factors on the variations in the displacement and stress of the hanging wall surface of the fault, footwall surface of the fault, and water-resistant coal pillar. These measurement points were designated D1 - D12 and S1 - S11. Six measurement points were established at the hanging wall and footwall surfaces of the fault and were labelled I1-1 - I16 and I2-1 - I2-6, respectively. The measurement points at the fault surface were used to monitor the normal displacement, tangential displacement, normal stress and shear stress at the respective locations. A detailed layout of the measurement points is shown in Fig. 4. 


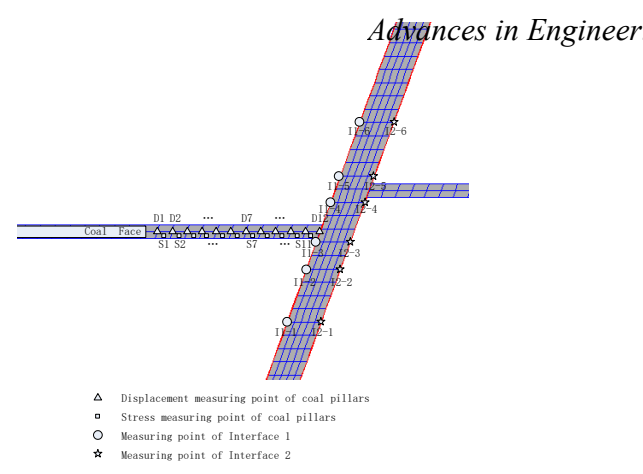

Fig. 4 Layout of measurement points during the simulation analysis

F. Displacement and Stress Analysis of the Coal Pillar at the Fault

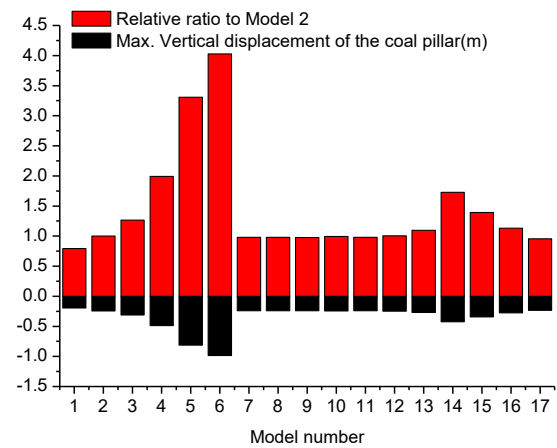

Fig. 5 Maximum vertical displacement of the coal pillar (the ratio shown is based on model two)

Fig. 5 gives the maximum vertical displacement of the coal pillar at the fault calculated using the seventeen models, as well as the ratio of the displacement calculated using all models to the displacement calculated using model two, which was selected as the benchmark because it is based on actual geological conditions. The effects of different burial depths on the maximum vertical displacement of the water-
Reseataht volume pillar at the fault can be evaluated using the outputs of models one to six. The maximum vertical displacement increased with increasing burial depth of the coal seam. When the burial depth of the coal seam was $\mathrm{H}<600 \mathrm{~m}$, each $100 \mathrm{~m}$ increase in the burial depth of the coal seam resulted in a $20 \%$ increase in the maximum vertical displacement. Additionally, when the burial depth of the coal seam was $\mathrm{H}>600 \mathrm{~m}$, a $100 \mathrm{~m}$ increase in the burial depth of the coal seam resulted in a $70-130 \%$ increase in the maximum vertical displacement. The effect of the throw of the fault and the water pressure of the aquifer on the maximum vertical displacement can be evaluated using model two and models seven to thirteen. Although the maximum vertical displacement increased with increasing water pressure in the aquifer, the effects of the throw of the fault and the aquifer water pressure on the maximum vertical displacement were less significant than were those of other impact factors. An exponential relationship was observed between the maximum vertical displacement of the coal pillar and the burial depth, as well as the coal pillar width, as shown in Eq. (7). The parameters that were acquired by regression are shown in Table 5. The effect of the width of the water-resistant coal pillar at the fault on the maximum vertical displacement is demonstrated by models two and fourteen to seventeen. The maximum vertical displacement decreased with increasing width of the water-resistant coal pillar at the fault, but the percentage of this reduction decreased from $0.91 \%$ to $0.23 \%$ with unit increases in the coal pillar width. This is expressed as follows:

$$
y=y_{0}+A e^{-X / t}
$$

where $y_{0}$ is the offset, $A$ is the amplitude, and tis the decay constant.

TABLE V. REGRESSED PARAMETERS

\begin{tabular}{|c|c|c|c|c|}
\hline \multirow[b]{2}{*}{ Parameter } & \multicolumn{2}{|c|}{ Function between displacement and depth } & \multicolumn{2}{|c|}{ Function between displacement and coal pillar width } \\
\hline & Value & Standard Error & Value & Standard Error \\
\hline $\mathbf{y}_{\mathbf{0}}$ & -0.135 & 0.0242 & -0.0865 & 0.0999 \\
\hline $\mathbf{A}$ & -0.006 & 0.0026 & -0.8063 & 0.0919 \\
\hline $\mathbf{t}$ & -162.198 & 13.0581 & 29.9038 & 13.2205 \\
\hline
\end{tabular}

The effects of the width of the water-resistant coal pillar at the fault on the maximum vertical displacement and stress of the coal pillar are shown in Fig. 6 and Fig. 7.

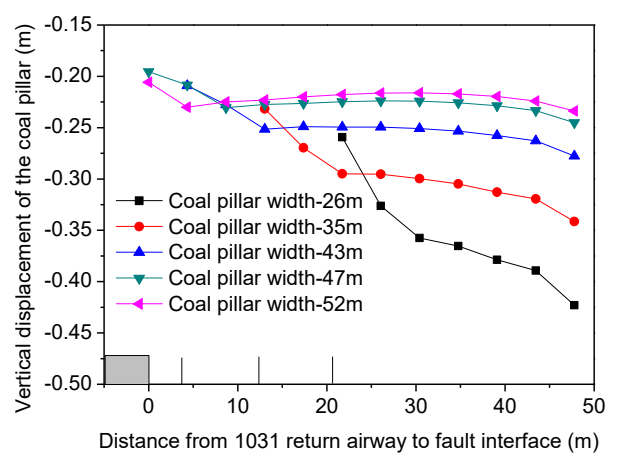

Fig. 6 Effect of the coal pillar width at the fault on the vertical displacement of the coal pillar

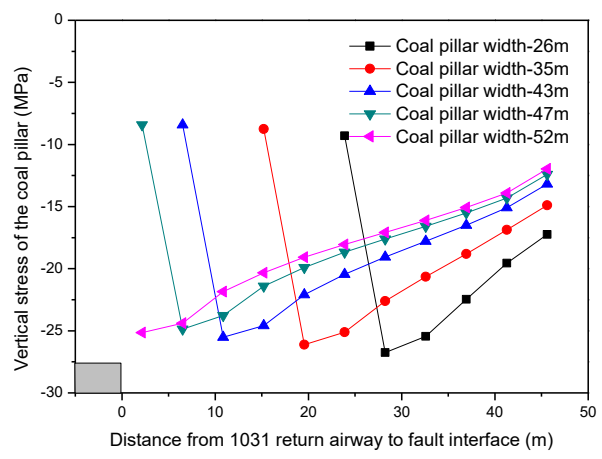

Fig. 7 Effect of the coal pillar width at the fault on the vertical stress of the coal pillar 


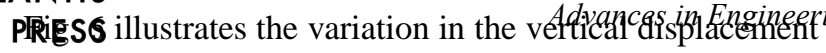
of the coal pillar with the distance between the measurement points and the air return roadway of Panel 1031 when the widths of the water-resistant coal pillar at the fault, L, are 26 $\mathrm{m}, 35 \mathrm{~m}, 43 \mathrm{~m}, 47 \mathrm{~m}$, and $52 \mathrm{~m}$. Fig. 6. suggests that when $\mathrm{L} \geq 43 \mathrm{~m}$, the vertical displacement of the water-resistant coal pillar at the fault first increased and then decreased. Then, it increased again with increasing distance between the measurement points and the air return roadway of Panel 1031. When $\mathrm{L}<43 \mathrm{~m}$, the vertical displacement of the coal pillar increased with increasing distance between the measurement points and the air return roadway of Panel 1031. A smaller coal pillar width resulted in a larger degree of variation, and, thus, a higher degree of fault activation.

Fig. 7 demonstrates the relationship between the vertical stress of the water-resistant coal pillar at the fault and the width of the water-resistant coal pillar at the fault. This relationship coincided with the correlation between the vertical displacement of the coal pillar and the other various factors, validating the functional relationship between vertical displacement and stress.

\section{G. Analysis of Displacement and Stress at the Fault Surface}

Figs. 8 and 9 demonstrate the maximum normal and tangential displacements, respectively, at the hanging wall and footwall surfaces of the fault, as calculated using the seventeen design parameters.

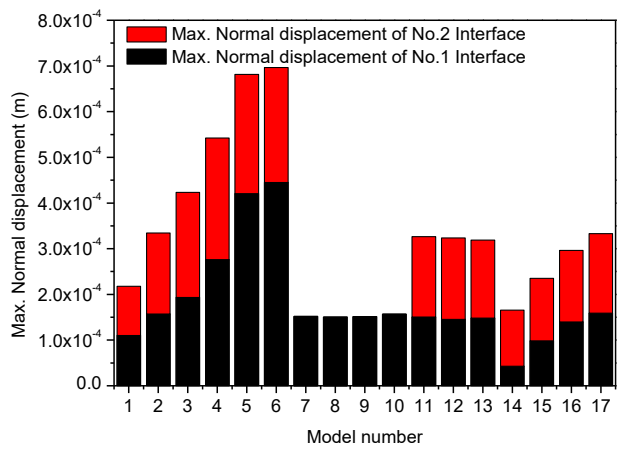

Fig. 8 Maximum normal displacement at the hanging wall and footwall surfaces of the fault

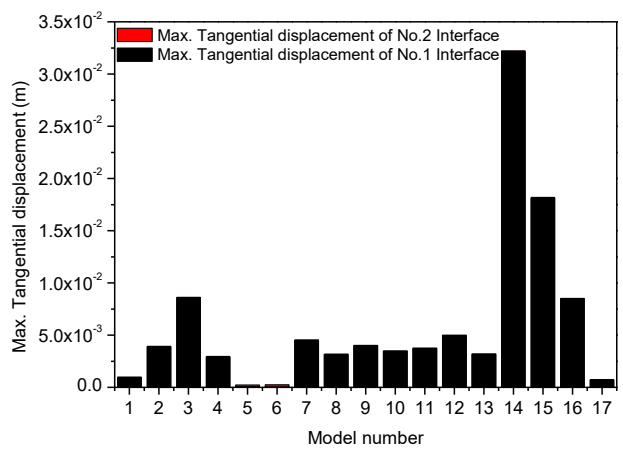

Fig. 9 Maximum tangential displacement at the hanging wall and footwall surfaces of the fault

As shown in models one to six in Figs. 8 and 9, the maximum normal displacement increased with increasing burial depth of the coal seam at the hanging wall surface of the fault. At the footwall surface of the fault, the maximum normal displacement first increased and then decreased with increasing burial depth of the coal seam. The relative variation in the maximum normal displacement at the hanging wall surface was larger than that at the footwall surface. The tangential displacement at the hanging wall surface of the fault first increased and then decreased with increasing burial depth of the coal seam. However, the
Resegeritialotusplacement at the footwall surface of the fault first increased with increasing burial depth of the coal seam. This phenomenon was caused by variations in the respective stresses, and Fig. 9 shows that the tangential displacement at the footwall surface due to any factor can be ignored with respect to that at the hanging wall surface.

The effects of the fault throw and aquifer water pressure on the maximum normal and tangential displacements at the hanging wall and footwall surfaces are demonstrated by model two and models seven to thirteen in Figs. 8 and 9. The maximum normal and tangential displacements at the hanging wall surface of the fault were affected to a small degree by the variations in the fault throw and water pressures because their respective stress variations were small. However, normal and tangential displacements at the footwall surface were only observed in model two, and the effect of water pressure was negligible.

Model two and models fourteen to seventeen demonstrate the effects of the width of the water-resistant coal pillar at the fault on the maximum normal and tangential displacements at the hanging wall and footwall surfaces in Figs. 8 and 9. The comparison suggests that the maximum normal displacement at both the hanging wall and footwall surfaces increased with increasing coal pillar width, and the tangential displacement decreased. This trend occurs because the normal stress increases with increasing coal pillar width, but the shear stress decreases with increasing coal pillar width, as shown in Fig. 10. The ratio of the maximum tangential displacement to the other displacement variations was approximately 200:1 at the hanging wall surface of the fault. Detailed data are provided in Fig. 11. Generally, the degree of activation of the fault surface increased with decreasing coal pillar width.

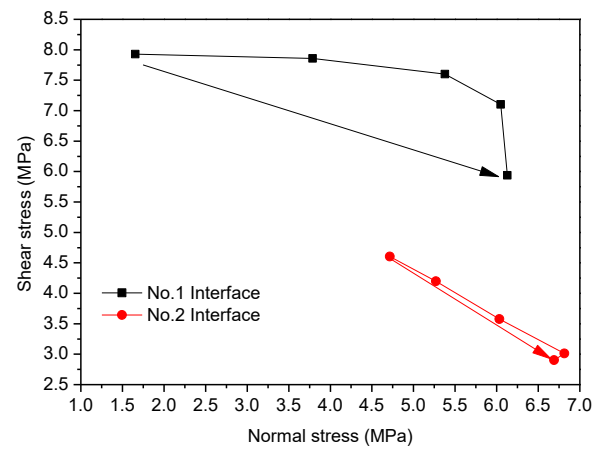

Fig. 10 Stress paths of measurement points at the hanging wall and footwall surfaces at different coal pillar widths

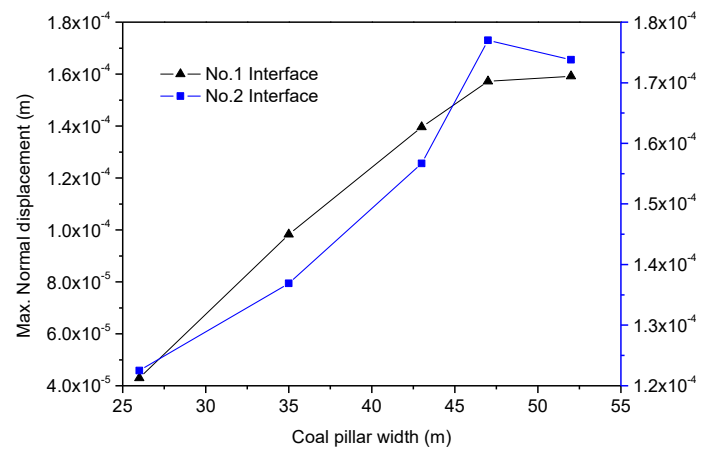

(a) Effect of coal pillar width on the normal displacements at the hanging wall and footwall surfaces 


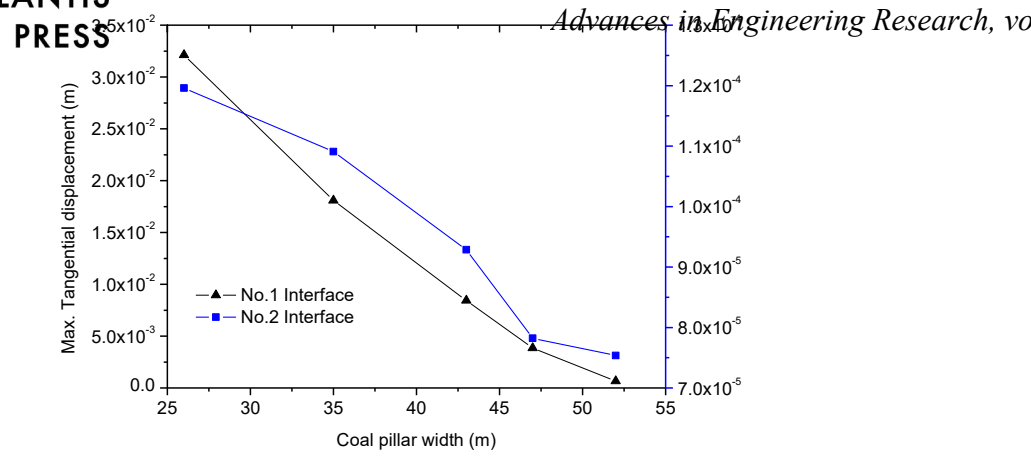

(b) Effect of coal pillar width on the tangential displacements at the hanging wall and footwall surfaces

Fig. 11 Effect of coal pillar width on the normal and tangential displacements at the hanging wall and footwall surfaces

\section{H. Analysis of the plastic damage state}

In this section, the effects of different widths of the water-resistant coal pillar at the fault on the damage fracture zone at the working face floor and fault activation are explained in detail. Fig. 12 gives the results of model two and models fourteen to seventeen in Table 4, in which the process of water inrush at the working face induced by decreasing the coal pillar width is clearly demonstrated. Due to the severe variations in pressure between the supporting pressure zone at the side of the coal pillar in the working face and the pressure unloading zone at the gob, the floor was damaged in front of the working face, and new cracks were produced in the lower portion of the overlying rocks above the aquifer as a result of mining activity. The region where new cracks were produced is called the aquifer ascending area, or the 3A zone, as shown in Fig. 12(a). As the width of the water-resistant coal pillar decreased, the damage zone at the floor extended deeper into the rock, but the 3A zone was not affected significantly. Thus, the waterproof stratum still possessed a certain degree of water resistance, as shown in Figs. 12(b) and 12(c). Due to the fault and the effects of mining at the working face, the depth of the damage in the floor at the side proximal to the fault was more severe, and limited activation occurred in rocks close to the fault and the fault itself. This promoted conditions for the formation of water inrush channels in the mining damage zone and the fault activation zone, as shown in Figs. 12(c) and 12(d). When the width of the water-resistant coal pillar at the fault was reduced to $35 \mathrm{~m}$, the $3 \mathrm{~A}$ zone expanded due to the combined actions of the mining pressure and the confined water pressure, and new cracks were produced in the damage zone of the floor and near the fault activation zone. The existing cracks expanded further and converged, leading to the formation of a water channel, i.e., the intermediate region between the two yellow lines. Water inrush occurred at the working face, and a certain degree of damage was observed in the waterproof stratum in the floor, as shown in Fig. 12(d). As the width of the water-resistant coal pillar at the fault further decreased, the waterproof rock stratum of the floor was completely damaged, and the fault activation zone continued to expand, leading to the formation of numerous water channels and high-intensity water inrush at the working face, as shown in Fig. 12(e).

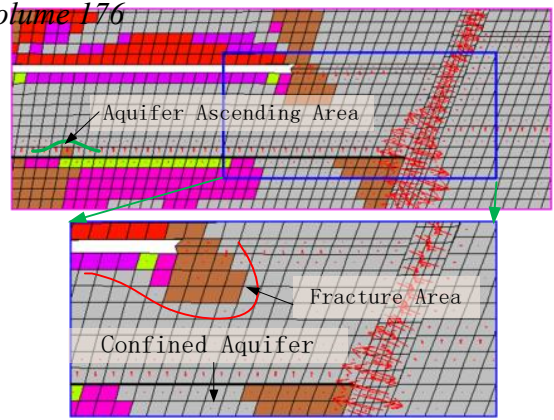

(a)

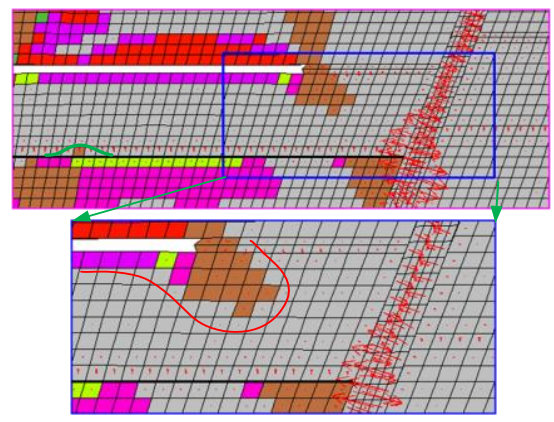

(b)

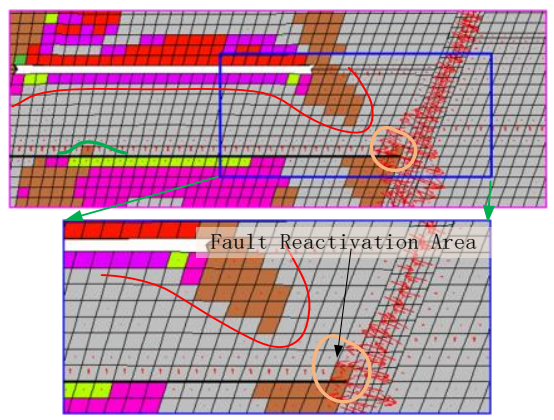

(c)

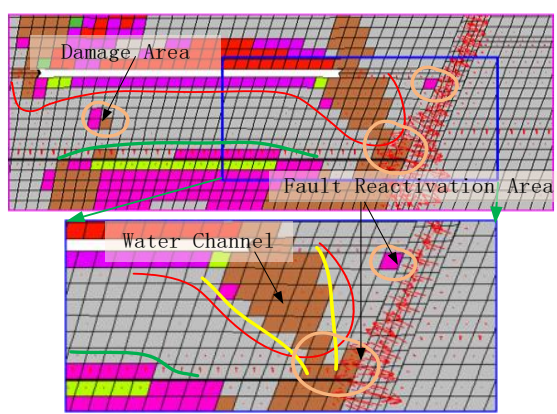

(d)

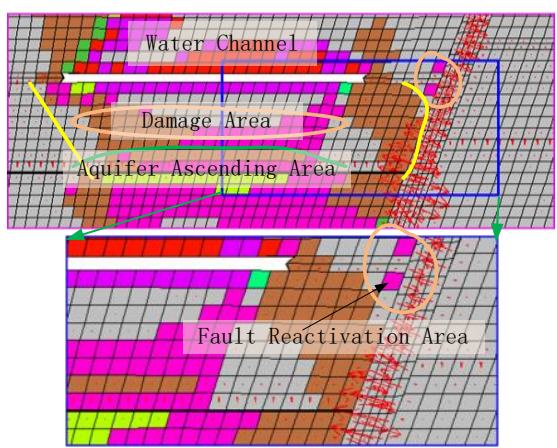

(e)

Fig. 12 Evolution of water inrush induced by decreasing the width of the water-resistant coal pillar at the fault 
Using site-specific geological conditions at an underground coal mine, this study evaluated the damage and fracture patterns of the floor and fault activation zone during longwall mining using numerical simulations. The following conclusions can be drawn from this research:

1) When the working face approached the fault, high stress concentrations were observed at the roof and floor of the coal pillar. Therefore, the degrees of damage to the coal pillar and floor close to the fault were higher than those in other areas. As the width of the water-resistant coal pillar decreased, the risk of water inrush at the working face significantly increased.

2) A comprehensive analysis of the results of the numerical calculations showed that under conditions in which other impact factors were identical, the risk of water inrush at the floor was higher for a rock stratum with a higher permeability. The higher the water pressure in the aquifer is, the more likely the occurrence of water inrush at the working face.

3) The damage in the floor and fault activation zone under the combined actions of the mining stress field and seepage field is affected by a number of factors, including the burial depth of the coal seam, the confined water pressure, the throw of the fault, and the width of the waterresistant coal pillar at the fault, all of which significantly affect the formation of water inrush channels at the working face. The larger the burial depth of the coal seam, confined water pressure, and throw of the fault, the higher the risk of water inrush. Additionally, the larger the width of the waterresistant coal pillar at the fault, the lower the chance that water inrush will occur. The effects of these four impact factors on water inrush at the working face and fault activation zone were compared. We found that the effects of the burial depth of the coal seam and the width of the waterresistant coal pillar at the fault were significant. The effect of the confined water pressure was less significant, and the throw of the fault was least significant. The mechanism of the formation of water inrush at the working face was demonstrated by decreasing the width of the water-resistant coal pillar at the fault, which in turn led to water inrush. The formation of water inrush channels can be attributed to various degrees of rock damage due to mining, as well as the stress field and seepage field.

\section{ACKNOWLEDGMENT}

The study presented in this paper was jointly supported by grants from the National Natural Science Foundation of China (grant no. 51379119, 51509149, and 41472281); Key Laboratory of Safety and High-efficiency Coal Mining, Ministry of Education (grant no. JYBSYS2014106); and National key research and development plan( grant no. 2017YFC0804108).

\section{REFERENCES}

[1] Huang C. Study on water inrush mechanism of mining fault. Dissertation, 2010, Central South University

[2] He M, Xie H, Peng S, Jiang YD. Study on rock mechanics in deep mining engineering. Chin J Rock Mec Eng. 2005, 24:2803-2813. doi: 10.3321/j.issn:1000-6915.2005.16.001.

[3] Miao X, Liu W, Chen Z. Dynamics of systems of seepage flow in surrounding rock affected by mining. 2004, Science Press, Beijing. archewolume, Z6o HX, Fa LT. Mechanics analysis on key route of water inrush from fault base on mining dynamics and under pressurized water role. Coal Eng, 2011, 5:70-73. doi: 10.3969/j.issn.1671-0959.2011.05.028.

[5] Guan E. Characteristics of floor water irruption of fault and forecast methods in Yanmazhuang coal mine. Coal Eng. 2005, 7:43-45. doi: 10.3969/j.issn.1671-0959.2005.07.017.

[6] Yu G, Xie H, Yang L. Numerical simulation of fractal effect induced by activation of fault after coal extraction. J China Coal Soc. 1998, 23:396-400. doi: 10.13225/j.cnki.jccs.1998.04.013.

[7] Pan Y. An inquiry of secure hydraulic head formula of slisalif' s. J Hefei Polytech Univ. 1986, 8:99-103.

[8] Li B. "Down Three Zones" in the prediction of the water inrush from coalbed floor aquifer-theory, development and application. J Shandong Inst Min Technol (Nat Sci). 1999, 18:11-18.

[9] Liu Q. A discussion on water inrush coefficient. Coal Geol Explor. 2009, 37:34-37. doi: 10.3969/j.issn.1001-1986.2009.04.009

[10] Wang J, Wang X. Discussion on water inrush coefficient method applied to predict water inrush danger of seam floor. Coal Sci Technol.2011,39:106-111.doi: 10.13199/j.cst.2011.07.112.wangjt.027.

[11] Zhang J, Zhang Y, Liu T. Rock seepage and water inrush of seam floor. 1997, Geological Press, Beijing.

[12] Jing Z, Li B. Mechanism of water inrush in coal seam floor. Coal Geol Explor . 1980, 2:51-56.

[13] Li BY, Mi SZ. Mining engineering hydrogeology. Shandong Institute of Mining and Technology Press, 1988, Tai' an

[14] Wang Z, Liu H. Coal mining above confined Aquifer. 1992, Coal Industry Press, Beijing.

[15] Qian M, Miao X, Xu J. Theoretical study of key stratum in ground control. J China Coal Soc. 1996, 21:225-230. doi: 10.13225/j.cnki.jccs.1996.03.001.

[16] Hu X, Wang L, Lu Y, Yu M. Analysis of insidious fault activation and water inrush from the mining floor. Int J Min Sci Technol. 2014, 24:477-483. doi: 10.1016/j.ijmst.2014.05.010.

[17] Peng S, Meng Z, Li Y. Influence of faults on coal roof stability by physical modeling study. Coal Geol Explor. 2001, 29:1-4. doi: 10.3969/j.issn.1001-1986.2001.03.001

[18] Zuo J, Chen Z, Wang H, Liu X, Wu Z. Experimental investigation on fault activation pattern under deep mining. J China Coal Soc. 2009, 34:305-309. doi: 10.13225/j.cnki.jccs.2009.03.006.

[19] Li Z, Dou L, Lu Z, Lu X, Wang G. Study of the fault slide destabilization induced by coal mining. J Min Saf Eng. 2010, 27:499504. doi: 10.3969/j.issn.1673-3363.2010.04.010

[20] Li K, Mao XB, Chen L, Zhang LY. Research on fault activation and risk analysis of water inrush in mining floor above confined aquifer. Chin Q Mech. 2011, 32:261-268. doi: 10.15959/j.cnki.02540053.2011.02.010.

[21] Liu Z, Hu Y. Solid-liquid coupling study on water inrush through faults in coal mining above confined aquifer. J China Coal Soc. 2007, 32:1046-1050. doi: 10.13225/j.cnki.jccs.2007.10.016

[22] Zheng S, Zhu W, Wang S. Study on the coupling problem between flow and solid of mine in confined aquifer. Chin J Rock Mech Eng. 2000, 19:421-424.doi: 10.3321/j.issn:1000-6915.2000.04.005.

[23] Zhang PS,Yang J,Wang MH,Wang H. Experimental research on fault activation and water inrush induced by mining under solid-liquid coupling mode. Saf Coal Min. 2014, 45:24-27. doi: 10.13347/j.cnki.mkaq.2014.03.007.

[24] Zhang PS, Zhang WQ,Wang MH,Wang H. Numerical simulation of sliding rule of two plates of fault induced by mining under solidliquid coupling mode. J Shandong Univ Sci Technol (Nat Sci). 2014, 33:53-57. doi: 10.3969/j.issn.1672-3767.2014.02.008.

[25] Zhang PS, Yang J,Wang MH,Wang H. Simulated study on variation of interfacial stress of fault induced by mining under solid-liquid coupling mode. China Min Mag. 2014, 23:84-89. doi: 10.3969/j.issn.1004-4051.2014.04.020.

[26] Yang T, Tang C, Xu T. Flow characteristics during rock failure process: Theory, models and applications. 2004, Science Press, Beijing.

[27] $\mathrm{Bu} \mathrm{W,} \mathrm{Mao} \mathrm{X.} \mathrm{Research} \mathrm{on} \mathrm{effect} \mathrm{of} \mathrm{fault} \mathrm{dip} \mathrm{on} \mathrm{fault} \mathrm{activation} \mathrm{and}$ water inrush of coal floor. Chin J Rock Mech Eng. 2009, 28:386-394. doi: 10.3321/j.issn:1000-6915.2009.02.024.

[28] Feng MM, Mao XB, Bai HB, Miao XX. Analysis of water insulating effect of compound water-resisting key strata in deep mining. J China Univ Min Techol. 2007, 17:1-5, doi:10.1016/S1006-1266(07)60001-7. 


\section{ATLANTIS}

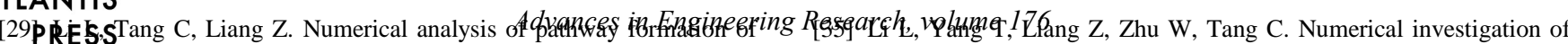
groundwater inrush from faults in coal seam floor. Chin J Rock Mech Eng. 2009, 28:290-297.doi: 10.3321/j.issn:1000-6915.2009.02.010.

[30] Yang TH, Liu J, Zhu WC, Elsworth D, Tham LG, Tang CA. A coupled flow-stress-damage model for groundwater outbursts from an underlying aquifer into mining excavations. Int J Rock Mech Min Sci. 2007, 44:87-97. doi: 10.1016/j.ijrmms.2006.04.012.

[31] [31]Tan J, Ju Y, Zhang W, Tan YJ. Structure controls on present geothermal field in Sulin mine area of Huaibei. J China Coal Soc. 2009, 34:449-454. doi: 10.13225/j.cnki.jccs.2009.04.002

[32] Ju Y, Wang G. Tectonic characteristics and evolution of the Sulin mine area in the Huaibei coalfield. J Liaoning Tech Univ (Nat Sci Edn). 2002, 21:286-289. doi: 10.3969/j.issn.1008-0562.2002.03.010.

[33] Wang G, Jiang B, Cao D, Zou H. On the Xuzhou-Suzhou arcuate duplex-imbricate fan thrust system. Acta Geol Sin. 1998, 72:228-236.

[34] ITASCA. FLAC3D-fast lagrangian analysis of continua, 4th ed. ITASCA Consulting Group Inc., 2009, USA.

groundwater outbursts near faults in underground coal mines. Int $\mathrm{J}$ Coal Geol. 2011, 85:276-288. doi: 10.1016/j.coal.2010.12.006.

[36] Sainoki A, Mitri HS. Dynamic behavior of mining-induced fault slip. Int J Rock Mech Min Sci. 2014, 66:19-29. doi: 10.1016/j.ijrmms.2013.12.003

[37] Jiang Y, Wang T, Zhao Y, Wang C. Numerical simulation of fault activation pattern induced by coal extraction. J China Univ Min Technol. 2013, 42:1-5.

[38] Brown ET, Hoek E. Technical note: trends in relationships between measured in-situ stress and depth. Int J Rock Mech Min Sci Geomech Abstr. 1978, 15:211-215. doi: 10.1016/0148-9062(78)91553-X.

[39] Zhao D, Chen Z, Cai X, Li S. Analysis of distribution rule of geostress in china. Chin J Rock Mech Eng. 2007, 26:1265-1271. doi: 10.3321/j.issn:1000-6915.2007.06.024.

[40] Wu Q, Pan G, Guan E. A study review of water inrush hazards in Jiaozuo mining region. Chin J Geol Hazard Control. 1995, 6:44-49. doi: 10.16031/j.cnki.issn.1003-8035.1995.04.007. 